\title{
Exploring the Ummatic Personality Dimensions from the Psycho-spiritual Paradigm
}

\author{
Nooraini Othman \\ UTM Perdana School, Universiti Teknologi Malaysia \\ International Campus, Jalan Semarak, Kuala Lumpur, 54100, Malaysia \\ Tel: 60-3-2615-4891_E-mail: p-noraini@utm.my/khairunnur69@yahoo.com
}

$\begin{array}{lcc}\text { Received: June 1, } 2011 & \text { Accepted: June 14, } 2011 \quad \text { Published: December 1, } 2011 \\ \text { doi:10.5539/ijps.v3n2p37 } & \text { URL: http://dx.doi.org/10.5539/ijps.v3n2p37 }\end{array}$

\begin{abstract}
The Ummatic Personality Inventory (UPI) ${ }^{\odot}$ was devised within a specific framework. It intends to be an assessment tool for self-introspection (muhasabah) and self-improvement (islah). Central to this idea is the concept that one would be able to identify the area where improvements could be made as far as one's personality as a Muslim is concerned. This research was conducted at two universities. The sample size was 588. The statistical method, Principal Component Analysis (PCA), was used. PCA was used to identify the underlying dimensions for each construct of the instrument. The results provide evidence that the developed instrument possesses sound psychometric properties. The reliability test indicated that the instrument was reliable, given that the overall reliability value of Cronbach's Alpha was .963 . The findings revealed that with the use of PCA, the Ibadah (worship) construct produced 5 significant factors, the Amanah (trust) construct generated 5 factors and the $I l m$ (knowledge) construct produced 2 factors. In conclusion, this study produced a prototype of the Ummatic Personality Inventory that possesses sound psychometric properties and contributes to the development of a novel psychological instrument from the Islamic perspective.
\end{abstract}

Keywords: Ummaticpersonality Inventory ${ }^{\odot}$, Muhasabah,Islah, PCA, Islamic psychology

\section{Introduction}

In describing personality, personality theorists have attempted to show similarities and differences among humans (Hergenhahn and Olson, 1999). The former issue concerns human nature, and the latter concerns individual differences. Thus, the goals of personality theory are to describe what humans are like and to explain why humans are like that. Hergenhahn and Olson (1999) further state that there is no single theory that has been completely successful at doing either; rather, different theories emphasize different aspects of human nature and individual differences.

Hasan Langgulung (2001) stresses that humans are the products of history, their problems and needs, their time and their environment. Western people created solutions and remedies based on their own problems and needs; however, Muslims have different problems and needs than those faced by the West. It is therefore only right for Muslims to have unique solutions and remedies to suit their own needs. He further argued that one of the dangers faced by Muslims is blind copying of the West. The Prophet SAW said: "One day you are going to fall blindly to the path of the people before you, even if they get into the lizard hole, you will fall too." This has been elaborated in detail by Malik Badri (2001) in his book, The Dilemma of Muslim Psychologists. In relation to the personality test inventory, Muslim scholars are encouraged to conduct research and develop their own original inventories based on the tenets of Islam. The issue of differing problems and needs, as raised by Langgulung (1991; 1985), can hopefully be addressed. Developing an original inventory will also reduce Muslims' dependence on the Western-created personality inventories, which are based on Western perspectives and values.

In his article, "An attempt towards an ummatic psychology," Khaleefa (1997) states that the reality of the ummah is that the present psychology in the ummatic culture is divorced from both the creative past of Islamic civilization and the creative present of Western thought. The spirit of imitation in psychology (modernization) has been exported from the West, not the techniques and methods (modernity). Muslims have taken from the past the spirit of imitation, not the spirit of vitality and productivity. Thus, it is time that Muslims realize the importance of having their own characteristics and traits so that they can develop a Muslim personality as individuals and as the ummah. 
To address these issues, the aim of this research was to develop an Ummatic Personality Inventory that is based on the Quran (the Muslim's Holy Scripture) and the Sunnah (the traditions of Prophet Muhammad). The main difference between this instrument and existing instruments is that the psycho-spiritual dimension is the one being measured. The name "Ummatic Personality Inventory" refers to a measurement tool consisting of items that were constructed based on the values adapted from the Quran and the Sunnah. This measurement tool was constructed by the researcher based on data collected from a document analysis and tested using the Principle Component Analysis (PCA) method because of its validity.

The term ummatic personality refers to the characteristics of an individual that are in accordance with Islamic spirituality, as described in the Quran and the Sunnah. The following statement is made in the Quran (Al-Isra': 85): "The spirit is from the command of my Lord."

The ummatic personality finds its basis in the Ummatic paradigm (Al-Faruqi, 1992) in which, according to Hasan Langgulung (1999), the main concern is restoring the spiritual element to the present materialistic basis of psychology, in other words, fostering the consideration of the Ruh or soul (the spiritual aspect of man) in understanding human behavior.

In addition, the essence of Islamic spirituality is the realization of the oneness of Allah (Tawhid). According to Al-Harran (2004), Islamic spirituality is a love colored and conditioned by knowledge and based on obedience already practiced and contained in living according to the Divine Law, which embodies God's concrete will for Muslims. He added that Islamic spirituality is also found in the Islamic rites that constitute the pillars of the faith. Thus, all our actions are considered acts of worship (Ibadah). Allah created man with a purpose - to serve Him - and made him different from other creatures, in such a way that he was raised to the level of khalifah, with responsibilities (amanah) and accountabilities. He was also given an intellect (aql) to enable him to seek knowledge $(\mathrm{ilm})$ and to put this knowledge into practice to benefit mankind.

The purpose of the study is to answer these research questions: What are the underlying dimensions (factors) of Psycho-Spiritual Personality characteristics? Is the construct valid and reliable? Is the construct multidimensional? It is proposed that ibadah, amanah and ilm shall be the constructs for the Ummatic Personality Inventory (Nooraini, 2008).

\section{Methods}

\subsection{Pilot Testing}

Pilot testing of the Ummatic Personality Test Instrument was conducted with 102 respondents. The instrument consisted of 103 item statements. Reliability analysis using the Cronbach's Alpha test revealed these results. The pilot testing indicated high scores for all three constructs of the UPI instrument (Table 1). After the revisions and deletions of items based on the result of item analysis and PCA, a total of 27 items were deleted from the instrument and 2 new items were added in $\mathrm{Ilm}$ construct. The final version of the instrument, with 78 items, is now ready for its real data collection.

\subsection{Respondents}

In the real data collection process, a total of 600 questionnaires were distributed among the respondents; 240 questionnaires were distributed among the students of University A and 360 were distributed among the students of University B. The researcher managed to collect 596 out of the 600 distributed questionnaires. After discarding incomplete questionnaires, a total of 588 completed questionnaires were selected as the sample for this study, which was a large enough sample to ensure statistical significance.

\subsection{Instrument}

The instrument used in this study was self-developed by the author based on the Quran, Sunnah and the works of the Muslim scholars. The final instrument after pilot testing consists of 78 items. Using PCA, the sample size depends on the number of items in the instrument. The minimum size is determined by the rule of thumb that there should be at least five times as many cases as there are variables to be analyzed (Hair, Anderson, Tatham \& Black, 1998; 2006).

\subsection{Data Analysis}

The data collected were analyzed using PCA. PCA was used to identify the underlying dimensions for each construct of the instrument. The reliability of each construct was based on the value of Cronbach's Alpha.

\section{Results}

Principal Component Analysis was run separately for each construct: Ibadah, Amanah, and Ilm. To determine the 
number of factors to retain, 4 criteria were used:

1. The presence of correlation with the other resulting factors (Barlett's test, KMO and MSA)

2. Factors with eigenvalues greater than 1.0.

3. The value of factor loading for each variable was greater than 0.40 .

4. A minimum of 4 items loaded for each factor.

\subsection{Ibadah Construct}

Bartlett's test was significant: $\chi^{2}(496)=7806.777, \rho=.001$. The overall measure of sampling adequacy (KMO) was .924. This result shows that there was a correlation between the items, and it supports the use of PCA in this study. The measurement of sampling adequacy (MSA) for each item showed that all of the values were greater than .80 .

PCA showed that there were 5 components generated by the data with eigenvalues greater than 1.0, accounting for $53 \%$ of the total variance described (Table 2). This indicates that five underlying dimensions explained more than $50 \%$ of the variance among the 30 variables.

Based on the contents of the items (Table 3), factor 1 was labeled Fardhu 'Ain (factor 1-12 items). The main purpose of the items in this factor is to measure the individual deeds performed according to syariah (Al-Quran and As-Sunnah). It is the internalization of the components of articles of faith, articles of Islam and the concept of Ihsan in an individual Muslim that is reflected in behavior.

Factor 2 was labeled Fardhu Kifayah-Deen (factor 2-4 items). This group of items measured individual participation in fulfilling the needs of society according to the first component of Maqasid Syariah, that is, the deen (religion). In particular, it refers to the protection of religion (Islam) and involvement in activities related to the uplifting of Islam.

Factor 3 was labeled Fardhu Kifayah-Nafs (factor 3-5 items). The items in this factor were meant to assess individual participation in fulfilling the needs of the society according to the second components of Maqasid Syariah, or nafs (self). This refers toone's willingness to contribute and sacrifice for the good of another human being.

Factor 4 was a combination of two factors, 'aql and mal, which were collapsed into one factor. The items belonging to 'aql were meant to measure individual activities in protecting the 'aql against insanity and were concerned with the soundness of mind and mental health. These items equally referred to the protection of intellect, which relates to intellectual development. The items that were meant for assessing mal indicate individual activities in the creation and protection of wealth, which is also concerned with economic well being. Hence, the researcher has named it Fardhu Kifayah-Aql \& Mal (Factor 4-6 items).

Factor 5 contains only 3 loaded items, labeled Fardhu Kifayah-Nasab (Factor 5-3 items). This group of items measured individual participation in the activities related to the protection of progeny, which includes the protection of offspring and the reproductive system. Even though it did not fulfill the criteria set beforehand, the researcher decided to retain this component as factor 5 because of the high loading on each item and the fact that these items did contribute to the importance of the dimension in the Ibadah construct. Item 19 was considered noise and was deleted from the instrument because it was only loaded with two factors. Thus, there were 30 items remaining in the Ibadah construct of the UPI instrument that fulfill the criteria of reliability and validity.

\subsection{Amanah Construct}

The Bartlett's test was significant: $\chi^{2}(435)=9928.088, \rho=.001$. The overall measure of sampling adequacy (KMO) was .943. This result shows that there is a correlation between the items. The measurement of sampling adequacy (MSA) for each items showed that all of the values were greater than .90.

Principal Component Analysis revealed that there were 5 components generated by the data with eigenvalues greater than 1.0 , accounting for $61.037 \%$ of the total variance explained (Table 4). This indicates that five underlying dimensions explain more than $60 \%$ of the variance among the 28 variables. Based on the contents of the items (Table 5), the factors were labeled accordingly. Factor 1 was labeled Khilafah-Amar Ma'aruf (factor $1-7$ items). This factor aimed to measure the personal deeds that reflect an understanding about the role of the khalifah, that is amar ma'ruf.

Factor 2 was labeled Khilafah-Nahi Munkar (factor 2-6 items). The group of items that belongs to this factor was meant to assess individual deeds that indicate awareness in fulfilling responsibilities as khalifah of Allah in forbidding evil. 
Factors 3, 4 and 5 were labeled accordingly as Accountability-Allah (factor 3-6 items), Accountability-Parents (Factor 4-3 items) and Accountability-Society (Factor 5-6 items). These factors were meant to measure the individual deeds that reflect an understanding and internalization of responsibilities toward the Creator and other human beings, including parents, friends and neighbors. Factor 5 is a combination of three factors - neighbors, friends and society - that have been collapsed into one factor. Hence, the researcher named it Accountability-Society. Factor 4 contains only 3 loaded items. Even though it does not fulfill the criteria specified beforehand, the researcher decided to retain the component as factor 5 because of the high loadings on each item and because they did contribute to the importance of the dimension in the Amanah construct.

Items 55 and 62 were considered noise and were deleted from the instrument because they were only loaded with two factors. Thus, there were 28 items remaining in the Amanah construct of the UPI instrument that fulfilled the criteria of reliability and validity.

\subsection{Ilm Construct}

Bartlett's test was significant: $\chi^{2}(120)=4601.341, \rho=.001$. The overall measure of sampling adequacy (KMO) was .944. This result shows that there is a correlation between the items. The measure of sampling adequacy (MSA) for each item showed that all values were greater than .90 .

Principal Component Analysis revealed that there were 2 components generated by the data with eigenvalues of more than 1.0, accounting for $54.699 \%$ of the total variance described (Table 6). This indicates that two underlying dimensions explained more than $50 \%$ of the variance among the 11 variables.

Based on the contents of the items (Table 7), the factors were labeled. Factor 1 was labeled Knowing (factor $1-5$ items). The items belonging to this factor indicate the reflection of one's understanding toward the theoretical part of knowledge. This factor measures the individual's views toward the importance of knowledge and learning. Factor 2 was labeled Doing (factor 2-6 items). The group of items in this factor is intended to assess the individual deeds in sharing and applying knowledge gained. Items 70, 72, 73, 74 and 76 were considered noise and were deleted from the instrument because they were only loaded with two factors. Thus, there were 11 items remaining in the $\mathrm{Ilm}$ construct of the UPI instrument that fulfilled the criteria of reliability and validity. The reliability test indicated that the instrument is reliable, given that the overall reliability value of Cronbach's Alpha is .963 (Table 8).

In summary, the analysis of this data provided good results by generating relevant factors that are consistent with the literature. The final version of the instrument contains 69 items.

\section{Discussion}

The discussion of the results is based on the results and findings generated from the statistical method, namely, from Principal Component Analysis (PCA), which produced the underlying factors for the instrument

Prior to the construction of the Ummatic Personality Inventory, PCA was used to assess the strength of the relationships between variables, to identify the number of factors present in the data and to identify items that did not load any factors or that were loaded on more than one factor. The results of PCA revealed the existence of several factors or dimensions generated from each construct of the developed instrument. The first construct, Ibadah, contained five underlying factors. These five factors are labeled as follows: Fardhu Ain, Fardhu Kifayah-Deen, Fardhu Kifayah-Nafs, Fardhu Kifayah- 'Aql \& Mal and Fardhu Kifayah-Nasab

Items in the factor labeled Fardhu 'Ain generally pertain to an individual's deeds in fulfilling responsibilities as a Muslim in accordance with the components of the articles of Islam, the articles of Iman(faith) and the concept of Ihsan (mindfulness). As a Muslim, each and every individual is required to abide by these articles and concepts because they are the cardinal principles and obligations imposed on the behavior of individuals. The performance of Fardhu 'Ain indicates one's degree of motivation and discipline in observing what is individually obligated upon the person.

By following the principles or articles of Islam and Iman, one is seen as performing the physical aspects of the obligations. The completeness of the two will be reached only through Ihsan, where the purity and sincerity of the heart represents taqwa. To show the highest degree of importance of these teachings, the angel Jibril came to the Prophet in human form. He was witnessed by the Prophet's companions and taught them on the matter, as the "hadith Jibril" relates.

The items related to Fardhu Kifayah denote the participation of individuals in performing the obligation in a collective or congregational manner. Here, following the analysis of al-Ghazali in his work al-Mustasfa, he underlined five items as the main elements to be addressed by Muslims. These elements were grouped together 
and termed al-maqasid al-syariah, which means the protection of the most essential elements, this being the intention of syariah itself. These essential elements are al-deen (religion of Islam), al-nasab (progeny/offspring), al-aqal (mind), al-mal (wealth) and al-nafs (self). The term maqasid is also translated from its Arabic root as the theory of the higher objectives and intents of Islamic Law as in Al-Raysuni's (2006) and Attia's (2007) translated works.

Relating to al-deen is aqidah, or one's faith in Allah (God). This is also important because it is the protection of the system of life prescribed by Islam, such as in education, politics and economics. This is in line with the Quranic command, "verily the only Religion in the sight of Allah is Islam." The same idea appears in another verse, "Oh believer, come to the fold of Islam in its entirety." The items in Fardhu Kifayah-Deen measure the individual's willingness and actions in protecting and promoting the values of Islam as a way of life.

The items related to Fardhu Kifayah-Nafs imply the need for taking care of oneself so that a person is individually fit and at the same time can contribute to others in any way possible. Al-nafs is about protecting the self. The self means the person. One of the highest degrees of self-dignity is being selfless; one's readiness to fight for what is right and contribute to the right course would be a good representation of this. Furthermore, a person's internal strength is reflected by his good behavior, which could also be a factor that would allow a person to contribute to a healthy environment. A person is protecting the self when he practices right conduct.

The items grouped as Fardhu Kifayah-'Aql \& Mal are a combination of items from 2 factors, 'Aql and Mal. Similar to al-aqal, these items are about protecting the mind and the brain itself. Both must remain healthy, so both must be nourished. The nourishment of the brain is good food and the nourishment of the mind is knowledge. It must be ensured that the brain remains functional in the healthiest manner possible and is protected from any element that may cause damage. When a malfunction of the brain occurs, the person does not function well. In medical terms, even if a person is breathing, if his brain is dead, he would be pronounced dead. This fact indicates the need to protect the brain.

This category is also concerned with taking care of the mind. A person who has lost his mind will be freed from liabilities. A more dangerous situation is when a person uses his mind to follow an unworthy course and bring about destructive results. In Islam, the mind must be put to good use and be well nurtured. Therefore, a good and balanced education system must be present as a means for producing good minds. Only good minds think well. This could perhaps be related to the verse of the Quran (Ali-Imran (3):191) that reminds us to think and reflect,

(Righteous are those) who are always mindful of Allah in their work, in their rest or in their sleep, who ponder the creation of heaven and earth, (and who conclude): O Lord, You have not created this in vain. To you is the praise. Protect us from the punishment of eternal fire.

The group of items related to al-Mal is about wealth creation and wealth protection. It is easy to understand that wealth must be protected. It could be lost, stolen or destroyed. What is less understood is that wealth must be created and put to good use. Muslims must build their own economy and become self-sufficient. They should also be able to assist other Muslims who are in need. Al-Mal is also about maintaining dignity, which is the reason why Islam forbids begging. It is also about 'aqidah. Many examples could be cited where, for a few pieces of bread, one's faith is being traded (i.e., being murtad or subscribing to another religion). The Prophet has warned about this: "The state of poverty is close to turning one into disbelievers."

The items related to al-Nasab are about protecting the future generation. This factor was labeled Fardhu Kifayah-Nasab. In the Quran, Allah says, "Be worried if you will leave behind you a weak generation."

This factor is also about protecting the social system. It becomes the responsibility of every Muslim to participate in and play a role as a member of the community in preventing the destruction of existing and future generations. This destruction could be from social problems, including drugs and sexual abuse. In addition, an individual Muslim should promote the building of excellent nations through lifelong learning and education.

The second construct, Amanah, signifies one's readiness to shoulder obligation without any violation of either the rules of Allah or a country's laws. It represents the self-concept of the person. The ultimate obligation of a person is to shoulder what has been described as the purpose of creation, that is, becoming khalifah. This is explained by Allah in the Quran (Al-Baqarah:30) regarding the creation of human beings: "And when your Lord said to the angels verily I am creating on the earth khalifah."

The responsibility and function of vicegerency or khilafah is to maintain and prosper the earth so that it will always be in good order. In the Quran (Hud: 61), Allah says the following: "And He is (you Lord) who gives you lives from earth and makes you the prosperor."

In a spiritual context, this is done through the process of amar ma'ruf and nahi munkar. The group of items that 
belongs to factor 1 was labeled Khilafah-Amar Ma'ruf.Amar ma'ruf means performing the tasks that lead to goodness. On the other hand, items that belong to factor 2 were labeled khilafah-Nahi Munkar. Nahi munkar forbids evil from being committed.

Naturally, when the two are combined together, the world will become a good place for all. When a person performs these two functions, he is in effect shouldering the amanah of the khalifah for this earth. Allah reminds us of this in the Quran (Ar-Rum:41): "Mischief has appeared on land and sea because of (the deed) that the hands of men have earned."

The items grouped as factor 3 were labeled Accountable-Allah. Being khalifah, people must always assume accountability for their deeds. A person will be accountable to Allah and, at the same time, to other people. Therefore, one's deeds must not in any way hurt people or go against the limitations set by Allah. Factor 4 contains a group of items that describes the responsibility and accountability of individuals toward their parents. This factor was labeled Accountability-Parents. Finally, factor 5 was named Accountability-Society because of the expression of the items that indicate responsibility toward neighbors, friends and the society as a whole. Thus, Amanah is also reflective of a person's integrity. The higher the degree of integrity that a person possesses, the better it will be for mankind. This indicates the readiness of a person to be responsible for his deeds (Zakaria, 1999).

The final construct, Ilm, produced two factors, namely, Knowing and Doing. Items related to Knowing (factor 1) measure the understanding and view of a person toward the importance of gaining knowledge. This concept is reiterated in the Quran (Al-Mujadalah: 11): "Allah will promote those among you who are faithful and those who possess knowledge to higher status."

Factor 2, which was labeled Doing, assesses the individual's efforts and actions in promoting the knowledge possessed, as well as in applying it as a contribution to society with the purpose of bringing prosperity to mankind.

\section{Conclusion}

The importance of having a good personality is supported by the Quran and the Sunnah, as well as in their interpretations by Muslim scholars. Thus, there is a need for Muslims to have their own method or tool for assessing personality from the Islamic perspective, given that the existing personality assessment instruments are based on Western perspectives and interpretations.

Based on this awareness, this research has been conducted as a humble attempt to try to fill the gaps in personality research from the point of view of Islam. The purpose of this study is to develop and validate a psychological instrument founded uponAl-Quran and As-Sunnah to measure and assess Muslim personality from the perspective of Islam. In this effort,the present researcher combines psychological and spiritual elements in developing the items for each proposed construct and their dimensions. The validity of the prepared items was tested using standard procedure and advanced statistical method. Therefore, this inventory serves as a self-assessment and self-improvement tool in measuring the level of personality of Muslim individuals in relation to the above constructs namely, ibadah, amanah and ilm. Muslim individual needs to understand his strength and weakness. The intention is not self-punitive, but it is more towards self-improvement. The best Muslim is certainly one who is closest to Allah and at the same time beneficial to the ummah. By understanding his strength, he will be able to perform his best from that particular angle. By understanding his weaknesses, he will be able to focus more on improving them. As a result, the individual will be more cautious in his deeds and that serves as his best motivation, as the effort to be a better person comes from within himself rather than being externally imposed.

\section{References}

Al-Faruqi, I. R. (1992).Al-Tawhid: Its implications for thought and life. Virginia: International Institute of Islamic Thought

Al-Harran, S. (2004).For today's sociall ills. Islam is the solution. Kuala Lumpur: A. S. Noordeen

Al-Raysuni, A. (2006).Iman Al-Syatibi's Theory of the objectives and intents of Islamic Law. Virginia: International Institute of Islamic Thought \& Kuala Lumpur: Islamic Book Trust

Ansari, M. F. U. R. (2001). The quranic foundations and structure of Muslim Society (Volume 1). Kuala Lumpur: Islamic Book Trust

Attia, G. E. (2007). Towards realization of the higher intents of Islamic Law-Maqasid al-Sayariah: A functional approach. Virginia: International Institute of Islamic Thought 
Aziz, U. I. (2000). Islamic personality and its development.Muslim Education Quarterly, 17(2), 61-68

Badri, M. (2001). Dilema ahli psikologi Islam. Kuala Lumpur: Medeena Books.

Hair, J. F., Anderson, R. E., Tatham, R. L., \& Black, W. C. (1998).Multivariate data analysis (5 ${ }^{\text {th }}$ edn.). New Jersey: Pearson Education, Inc.

Hair, J. F., Black, B., Babin, B., Anderson, R. E., \& Tatham, R. L. (2006).Multivariate data analysis (6 $6^{\text {th }}$ edn.). New Jersey: Pearson Education, Inc

Hammudah, 'A. (1984). Islamic social system: Its dimensions and characteristics, in M. Tariq Quraishi (ed.). Islam: A way of life and movement. Indiana: American Trust Publications.

Hergenhahn, B. R., \& Olson, M. H. (1999). An introduction to theories of personality. New Jersey: Prentice Hall Khaleefa, O. H. (1997). The imperialism of Euro-American psychology in a nonwestern culture: An attempt toward an ummatic psychology. The American Journal of Islamic Social Sciences, 14(1)

Langgulung, H. (1985). Pendidikan dan Peradaban Islam: Suatu Analisis Sosio-Psikologi. Jakarta: Pustaka Al-Husna

Langgulung, H. (1991). Integrated personality and integrated education: A psycho-spiritual approach. Muslim Education Quarterly, 8(4). 32-43

Langgulung, H. (1999). The ummatic paradigm of psychology. Kuala Lumpur: Univision Press

Langgulung, H. (2001). Islamisasi pendidikan dari perspektif metodologi. Jurnal Pendidikan Islam, 9(3). 17-32

Louay, S. (1996). The foundation of knowledge: A comparative study of Islamic and Western methods of inquiry. Kuala Lumpur: International Islamic University Press

Smith, Joe. (1999), One of Volvo's core values. [Online] Available: http://www.volvo.com/environment/index.htm (July 7, 1999)

Najati, M. U. (1968). 'ilmu an-nafs al-Islami. Mesir: Darus Syuruk

Nik Mustapha Nik Hassan. (1994). The relevance of human centred development in the industrial era. IKIM Journal, 2(1), 79-92

Nooraini Othman. (2008). The Development and Validation of the Ummatic Personality Inventory. Skudai: Universiti Teknologi Malaysia Publisher

Raba, A. M. (2001). Major personalities in the Quran. Kuala Lumpur: A. S. Noordeen

Ridwan, A. W. (1994). Islam, a misunderstood religion: Muslims, a misunderstood community. IKIM Journa, 2(1), 46-66

Zakaria, S. (1999).Akidah dan akhlak dalam kehidupan Muslim. Kuala Lumpur: Utusan

Table 1. Cronbach's Alpha results for pilot testing

\begin{tabular}{|c|c|c|c|}
\hline Constructs & No. of Variables & Alpha & $\begin{array}{c}\text { Standardized } \\
\text { Item Alpha }\end{array}$ \\
\hline Ibadah & 53 & .906 & .916 \\
\hline Amanah & 34 & .920 & .925 \\
\hline Ilm & 16 & .838 & .859 \\
\hline Overall Cronbach's Alpha for the instrument: .956 \\
\hline
\end{tabular}

Table 2. Eigenvalues and total variance explained for Ibadah construct

\begin{tabular}{|l|l|l|l|}
\hline \multicolumn{4}{|c|}{ Initial Eigen Values } \\
\hline Component & Total & \% of Variance & Cumulative \% \\
\hline 1 & 5.427 & 16.958 & 16.958 \\
\hline 2 & 3.205 & 10.016 & 26.974 \\
\hline 3 & 3.203 & 10.010 & 36.984 \\
\hline 4 & 2.703 & 8.446 & 45.430 \\
\hline 5 & 2.425 & 7.577 & 53.007 \\
\hline \multicolumn{4}{|l}{} \\
\hline
\end{tabular}


Table 3. Rotated component matrix for Ibadah construct

\begin{tabular}{|c|c|c|c|c|c|}
\hline \multirow[b]{2}{*}{ Variables } & \multicolumn{5}{|c|}{ Varimax-Rotated Loadings } \\
\hline & $\begin{array}{l}\text { Factor } \\
1\end{array}$ & $\begin{array}{l}\text { Factor } \\
2\end{array}$ & $\begin{array}{l}\text { Factor } \\
3\end{array}$ & $\begin{array}{l}\text { Factor } \\
4\end{array}$ & $\begin{array}{l}\text { Factor } \\
5\end{array}$ \\
\hline $\begin{array}{l}\text { I perform my prayers five times } \\
\text { daily. }\end{array}$ & .718 & & & & \\
\hline $\begin{array}{l}\text { I perform my prayers with full attention } \\
(k h u s y u k) \text {. }\end{array}$ & .488 & & & & \\
\hline I feel sad when Ramadhan ends. & .506 & & & & \\
\hline I recite the rites $(z i k r)$ for Allah. & 638 & & & & \\
\hline $\begin{array}{l}\text { I believe by remembering Allah I will be } \\
\text { closer to Him. }\end{array}$ & .563 & & & & \\
\hline $\begin{array}{l}\text { I realise that there are two angels recording } \\
\text { my deeds. }\end{array}$ & .513 & & & & \\
\hline I recite the Quran everyday. & .667 & & & & \\
\hline I act according to the teaching of the Quran. & .705 & & & & \\
\hline $\begin{array}{l}\text { I recite the praises (salawat) for the } \\
\text { Prophet. }\end{array}$ & .657 & & & & \\
\hline $\begin{array}{l}\text { I make continuous effort to internalise the } \\
\text { conducts of Rasulullah in my daily life. }\end{array}$ & 659 & & & & \\
\hline I take care of my conduct. & .506 & & & & \\
\hline $\begin{array}{l}\text { I obey every rule even if I personally } \\
\text { disagree with them. }\end{array}$ & .441 & & & & \\
\hline $\begin{array}{l}\text { I contribute my money towards the building } \\
\text { of a mosque. }\end{array}$ & & .612 & & & \\
\hline $\begin{array}{l}\text { I attend a meeting when invited to discuss } \\
\text { about Islam. }\end{array}$ & & .719 & & & \\
\hline I join Islamic functions. & & .691 & & & \\
\hline I give my things for Islamic charity. & & .670 & & & \\
\hline $\begin{array}{l}\text { I always believe that there is wisdom behind } \\
\text { every event. }\end{array}$ & & & .543 & & \\
\hline I support my friends who work for Islam. & & & .664 & & \\
\hline $\begin{array}{l}\text { I am willing to help the victims of natural } \\
\text { disaster. }\end{array}$ & & & .701 & & \\
\hline $\begin{array}{l}\text { I am prepared to fight for my country when } \\
\text { needed. }\end{array}$ & & & .564 & & \\
\hline $\begin{array}{l}\text { I will ensure that the food taken by me and } \\
\text { the family is halal. }\end{array}$ & & & .448 & & \\
\hline I schedule my time to avoid stress. & & & & .805 & \\
\hline I write my ideas properly. & & & & .801 & \\
\hline $\begin{array}{l}\text { I exercise my brain by thinking serious } \\
\text { matters. }\end{array}$ & & & & .663 & \\
\hline $\begin{array}{l}\text { I report to the authorities if I have proof of } \\
\text { bribery. }\end{array}$ & & & & .435 & \\
\hline I spend less and save more. & & & & .513 & \\
\hline I take care of my health. & & & & .533 & \\
\hline I join the effort to combat social ills. & & & & & .685 \\
\hline I participate in drug prevention efforts. & & & & & .834 \\
\hline $\begin{array}{l}\text { I participate in campaigns promoting } \\
\text { life-long learning. }\end{array}$ & & & & & .724 \\
\hline
\end{tabular}


Table 4. Eigenvalues and total variance explained for Amanah construct

\begin{tabular}{|l|l|l|l|}
\hline \multicolumn{4}{|c|}{ Initial Eigenvalues } \\
\hline Component & Total & \% of Variance & Cumulative\% \\
\hline 1 & 4.254 & 14.180 & 14.180 \\
\hline 2 & 4.239 & 14.131 & 28.311 \\
\hline 3 & 3.657 & 12.191 & 40.502 \\
\hline 4 & 3.502 & 11.675 & 52.177 \\
\hline 5 & 2.658 & 8.860 & 61.037 \\
\hline \multicolumn{4}{|l|}{ Total Variance Explained: $61.037 \%$} \\
\hline
\end{tabular}

Table 5. Rotated component matrix for Amanah construct

\begin{tabular}{|c|c|c|c|c|c|}
\hline \multirow[b]{2}{*}{ Variables } & \multicolumn{5}{|c|}{ Varimax-Rotated Loadings } \\
\hline & $\begin{array}{l}\text { Factor } \\
1\end{array}$ & $\begin{array}{l}\text { Factor } \\
2\end{array}$ & $\begin{array}{l}\text { Factor } \\
3\end{array}$ & $\begin{array}{l}\text { Factor } \\
4\end{array}$ & $\begin{array}{l}\text { Factor } \\
5\end{array}$ \\
\hline $\begin{array}{l}\text { I put effort to perform my duty as } \\
\text { khalifah. }\end{array}$ & 665 & & & & \\
\hline I can list down my role as khalifah. & .756 & & & & \\
\hline I persuade my friends to do good deeds. & 695 & & & & \\
\hline I am a good role model to my friends. & 671 & & & & \\
\hline $\begin{array}{l}\text { I help to improve the behavior of my } \\
\text { friends. }\end{array}$ & 770 & & & & \\
\hline $\begin{array}{l}\text { I consider any implications before taking } \\
\text { any action. }\end{array}$ & 565 & & & & \\
\hline $\begin{array}{l}\text { I give my advice when bad deeds occur in } \\
\text { front of me. }\end{array}$ & 568 & & & & \\
\hline $\begin{array}{l}\text { I report to the authority when I see people } \\
\text { committing crimes. }\end{array}$ & & 498 & & & \\
\hline $\begin{array}{l}\text { I advise my sister when they dress } \\
\text { inappropriately. }\end{array}$ & & 767 & & & \\
\hline $\begin{array}{l}\text { I continuously encourage my family to } \\
\text { cover their aurat. }\end{array}$ & & 784 & & & \\
\hline $\begin{array}{l}\text { I avoid socialisation that will lead to } \\
\text { forbidden relationship. }\end{array}$ & & 651 & & & \\
\hline $\begin{array}{l}\text { I report to the authority if I know any of } \\
\text { my friends take drugs. }\end{array}$ & & 626 & & & \\
\hline $\begin{array}{l}\text { I continuously encourage my friends } \\
\text { to cover theiraurat. }\end{array}$ & & 668 & & & \\
\hline I obey Allah in all matters. & & & .671 & & \\
\hline $\begin{array}{l}\text { I follow Allah's command and guidance } \\
\text { even when they are contrary to my } \\
\text { own desires }\end{array}$ & & & .591 & & \\
\hline $\begin{array}{l}\text { I seek the pleasure of Allah in everything } \\
\text { I do. }\end{array}$ & & & 658 & & \\
\hline I repent (taubat) to clear my sins. & & & .662 & & \\
\hline $\begin{array}{l}\text { I follow the advice of the Islamic scholars } \\
\text { (ulamak). }\end{array}$ & & & .656 & & \\
\hline $\begin{array}{l}\text { I recount my sins before I go to bed } \\
\text { every night. }\end{array}$ & & & 564 & & \\
\hline $\begin{array}{l}\text { I avoid using words of anger towards my } \\
\text { parents. }\end{array}$ & & & & .501 & \\
\hline $\begin{array}{l}\text { I pray for my parents in my daily } \\
\text { prayers. }\end{array}$ & & & & 673 & \\
\hline I obey my parents. & & & & .717 & \\
\hline
\end{tabular}


Continued (Table 5)

\begin{tabular}{|l|l|l|l|l|l|}
\hline $\begin{array}{l}\text { I take care of my neighbour's property if } \\
\text { he is not around. }\end{array}$ & & & & & .671 \\
\hline I take care of my friends' dignity. & & & & & .591 \\
\hline $\begin{array}{l}\text { I honour my friends in their presence and } \\
\text { absence. }\end{array}$ & & & & & .658 \\
\hline I never betray my friends. & & & & & .662 \\
\hline I realise that people watch my actions. & & & & & .656 \\
\hline $\begin{array}{l}\text { I am aware that I will be blamed for } \\
\text { my faults. }\end{array}$ & & & & & .564 \\
\hline The Bartlett's Test: $\chi^{2}(435)=9928.088, \rho<.001$. & & & \\
\hline
\end{tabular}

Table 6. Eigenvalues and total variance explained for $I l m$ construct

\begin{tabular}{|l|l|l|l|}
\hline \multicolumn{5}{|c|}{ Initial Eigenvalues } \\
\hline Component & Total & $\%$ of Variance & Cumulative $\%$ \\
\hline 1 & 4.595 & 28.719 & 28.719 \\
\hline 2 & 4.157 & 25.980 & 54.699 \\
\hline \multicolumn{2}{|l}{} \\
\hline
\end{tabular}

Table 7. Rotated component matrix for $I l m$ construct

\begin{tabular}{|l|l|l|}
\hline \multirow{2}{*}{ Variables } & \multicolumn{2}{|l|}{ Varimax-Rotated Loadings } \\
\cline { 2 - 3 } & Factor 1 & Factor 2 \\
\hline I regard learning from experience is very important. & .607 & \\
\hline I regard gaining knowledge as form of Jihad. & .576 & \\
\hline I feel closer to Allah when I gain more knowledge. & .664 & \\
\hline I regard study as a life-long effort. & .768 & \\
\hline I view problems as a challenge in life. & .741 & \\
\hline I share my ideas with others. & & .699 \\
\hline I make detailed analysis on a given issue. & & .827 \\
\hline I make continuous effort to internalise the knowledge I gain. & & .799 \\
\hline I apply the relevant knowledge in my daily life. & & .699 \\
\hline I contribute my idea in discussions. & & .679 \\
\hline I put effort to complete my task on time and efficiently. & & .554 \\
\hline The Bartlett's Test: $\chi^{2}(120)=4601.341, \rho<.001$. & \\
\hline
\end{tabular}


Table 8 . Reliability analysis

\begin{tabular}{|c|c|c|c|c|}
\hline Construct & Dimensions & $\begin{array}{c}\text { No. of } \\
\text { Variables }\end{array}$ & Alpha & $\begin{array}{l}\text { Standardised } \\
\text { Item Alpha }\end{array}$ \\
\hline \multirow[t]{6}{*}{ Ibadah } & & 30 & .918 & .920 \\
\hline & Fardhu 'Ain & 12 & .871 & \\
\hline & FardhuKifayah-Deen & 4 & .821 & \\
\hline & FardhuKifayah-Self & 5 & .681 & \\
\hline & FardhuKifayah-Aql\& Mal & 6 & .798 & \\
\hline & FardhuKifayah-Nasab & 3 & .801 & \\
\hline \multirow[t]{5}{*}{ Amanah } & Khilafah-Amar Ma'ruf & 7 & .876 & \\
\hline & Khilafah-NahiMunkar & 6 & .869 & \\
\hline & Accountability - Allah & 6 & .873 & \\
\hline & Accountability - Parents & 3 & .736 & \\
\hline & Accountability - Society & 6 & .849 & \\
\hline \multirow[t]{3}{*}{$\mathrm{Ilm}$} & & .892 & 11 & .888 \\
\hline & Knowing & 5 & .777 & \\
\hline & Doing & 6 & .870 & \\
\hline
\end{tabular}

